\title{
Serum and Urinary Proteins, Lysozyme (Muramidase), and Renal Dysfunction in Mono- and Myelomonocytic Leukemia
}

\author{
W. Pruzanski and M. E. Platts \\ From the Immunoproteins Research Laboratory of the University of Toronto \\ Rheumatic Disease Unit, Department of Medicine and Department of \\ Pathology, The Wellesley Hospital, Toronto, Canada
}

A в S т R A C T Serum levels, urinary excretion, and clearances of several proteins of different molecular weights were studied in 18 patients with mono- and myelomonocytic leukemia. Nine patients had normal renal function (group A) and nine had impaired renal function with azotemia (group B). The majority of patients in both groups had increased concentration of immunoglobulins, particularly IgG, IgA, and IgM; IgD level was normal. Serum transferrin and $\alpha_{2}$-macroglobulin were frequently reduced while the level of ceruloplasmin was often increased, especially in patients with azotemia. The activity of lysozyme in the serum was high in all patients, but was considerably higher in group $B$.

Proteinuria was found in most patients but was more prominent in group B. Almost invariably albumin constituted less than $25 \%$ of the total protein excreted. Qualitative analysis of various urinary proteins by immunochemical techniques and clearance studies suggested the presence of glomerular as well as tubular dysfunction. Determination of urinary lysozyme frequently showed no direct correlation between the serum level of the enzyme and its concentration in the urine or its clearance by the kidney. In addition to glomerular filtration, impaired tubular reabsorption may account for the high level of lysozyme in the urine. It is postulated that the very high level of lysozyme in the glomerular filtrate and possibly hypergammaglobulinemia may play a role in the induction of tubular damage. Renal impairment has been correlated with histological changes in the kidneys. From a comparative study of various leukemias, it seems that the combined glomerular-tubular dysfunction is a manifestation unique to mono- and myelomonocytic leukemia.

Received for publication 12 March 1970 and in revised form 25 May 1970.

\section{INTRODUCTION}

Hypogammaglobulinemia and susceptibility to infection have been well documented in various leukemias (1-3). However, a few authors have reported an increase rather than a deficiency of serum gammaglobulins in monocytic and myelomonocytic leukemia (4-8). Surprisingly, the literature contains little or no information concerning proteinuria in leukemia patients (9) and, with the exception of well documented uric acid nephropathy $(10,11)$, the problem of renal injury has been studied from a histologic rather than a functional point of view (12). The latter has recently assumed importance in view of the demonstration of increased levels of serum and urinary lysozyme (LZM) in mono- and myelomonocytic leukemia $(7,13)$. In addition to lysozymuria, other proteins have also been found in the urine of these patients. Some of them have had electrolyte disturbances with hypokalemia and hypomagnesemia $(7,14,15)$. Osserman and Azar have postulated that the abnormally high concentration of LZM in the renal cortex results in injury to the proximal tubular cells, thus contributing to the tubular dysfunction (16).

The present report concerns our observations on various serum and urinary proteins in 18 patients with mono- and myelomonocytic leukemia. It was found that a majority of the patients had hypergammaglobulinemia. Renal clearance studies of several proteins of different molecular weights, as well as immunochemical analyses of various urinary proteins suggested that these patients probably had both glomerular and tubular dysfunction. The determination of urinary LZM frequently showed no significant correlation between the serum level of the enzyme and the degree of lysozymuria, or its clearance by the kidney. In addition to glomerular filtration, it is possible that impaired tubular reabsorption and perhaps other mechanisms might be responsible for the high level of LZM in the urine. An attempt has 
also been made to correlate the histological changes in kidneys with the degree of functional impairment.

\section{METHODS}

18 patients with monocytic and myelomonocytic leukemia were divided into two goups (A and B) on the basis of their renal function. Group A consisted of nine patients having normal renal function. In this group, blood urea nitrogen (BUN), serum creatinine, and creatinine clearance were within the normal range. (Normal values were: BUN, $5-25 \mathrm{mg} / 100 \mathrm{ml}$; serum creatinine, male $0.9-1.4 \mathrm{mg} / 100 \mathrm{ml}$, female $0.8-1.2 \mathrm{mg} / 100 \mathrm{ml}$; creatinine clearance, $70-130$ $\mathrm{ml} / \mathrm{min}$.) Group $B$ consisted of nine patients having renal impairment with azotemia. A group of 20 healthy subjects and 250 patients with various diseases with or without renal failure served as controls. Data pertaining to this part of the study were reported elsewhere (17).

Samples of serum and urine were examined either immediately or stored at $-20^{\circ} \mathrm{C}$ for varying periods of time. When necessary, samples of urine were concentrated as much as 500 -fold, by dialysis in boiled seamless cellulose membranes against $25 \%$ polyvinylpyrrolidone or by negative pressure dialysis. Total protein was estimated by the biuret method (18). Microzone cellulose acetate electrophoresis was performed using $0.075 \mathrm{M}$ barbital buffer, $\mathrm{pH} 8.6$, and the membranes scanned in a Beckman's Analytrol. Immunoelectrophoresis was performed according to the technique of Grabar and Williams (19) with minor modifications. Antisera against whole human serum, $\operatorname{IgG}, \operatorname{IgA}, \operatorname{Ig}$, transferrin, ceruloplasmin, and $F_{c}$ and $F_{a b}$ fragments were obtained from Hyland Laboratories, Los Angeles, Calif. Rabbit anti-IgD antiserum (R133A) was kindly provided by the NCI Immunoglobulin Reference Center, Springfield, Va., courtesy of Dr. J. Fahey. This antiserum readily detected a level of $0.3 \mathrm{mg} / \mathrm{ml}$ of IgD. Anti-Bence Jones type kappa and lambda antisera and anti-human lysozyme antiserum were prepared in our laboratory by immunizing rabbits with purified Bence Jones proteins from urines of myeloma patients or with human LZM. Purified LZM was generously provided by Dr. E. F. Osserman, New York, and used in conjunction with our own material isolated from the urine of a patient with monocytic leukemia using the technique of Alderton, Ward, and Fevold (20). The purity of the isolated LZM was verified by electro- and inımunoelectrophoresis and by analytical ultracentrifugation. Immunoquantitation of $\operatorname{IgG}, \operatorname{IgA}$, IgM, transferrin, ceruloplasmin, and $\alpha_{2}$-macroglobulin was done using standard immunoplates obtained from Hyland Laboratories, and that of $\operatorname{IgD}$ using immunoplates of Kallestad Laboratories Inc., Minneapolis, Minn. The minimal concentration of IgD detectable by these plates was $0.02 \mathrm{mg} / \mathrm{ml}$. Lysozyme quantitation was performed by the lysoplate technique as described by Osserman and Lawlor (7). Lysozyme activity in the samples tested was compared to that of pure human lysozyme, microgram equivalent per milliliter of buffer. Prepared standards of pure human lysozyme containing 5, $25,100,250$, and $500 \mu \mathrm{g} / \mathrm{ml}$ were applied to each lysoplate and a semilog curve plotted. Analyses of urinary amino acids were kindly performed by Dr. S. H. Jackson, Hospital for Sick Children, Toronto, using one-dimensional thin-layer chromatography (21). Clearances of urinary proteins, creatinine, and uric acid were calculated on the basis of 24-hr collections of urine using the formula $\left(U_{c} \times U_{v}\right)$ / $\left(S_{c} \times 1440\right)=\mathrm{ml} / \mathrm{min}$. The clearances of eight proteins were determined; viz. lysozyme, mol wt 14,000-15,000 (7); transferrin, mol wt 73,000-76,000 (22) ; ceruloplasmin, mol wt 160,000 ; IgG, mol wt 160,000 ; IgA and $\operatorname{IgD}$, mol wt 160,000 or higher; $\alpha_{2}$-macroglobulin, $\mathrm{mol}$ wt 840,000 ; and IgM, mol wt 900,000 . The selectivity of protein excretion was examined by plotting the clearance values of IgG and $\alpha_{3}$-macroglobulin expressed as a percentage of transferrin clearance accepted as $100 \%$, against the respective molecular weights on double-log paper. The slope of the plotted line would be an expression of the selectivity and values exceeding a slope of $67^{\circ}$ were accepted as highly selective $(23,24)$. The estimation of BUN, uric acid, electrolytes, and creatinine was performed in the same sera and urines in which the proteins were determined. White blood cells were usually counted on the same day that the serum and urines were collected. In three patients, however, there was a lapse of $24-48 \mathrm{hr}$ between these determinations. Autopsy examination was performed in six patients with special attention directed to histological changes in the kidneys. The kidneys of seven additional patients with monocytic or myelomonocytic leukemia (not included in the present study) were also examined.

\section{RESULTS}

There were no significant differences in age or sex between groups A and B (Tables I and IV). The duration of the disease in group $\mathrm{A}$ varied from 2 wk to 48 months with a mean of 11 months. In group $B$, the duration ranged from 3 wk to 24 months, on the average, 5.1 months. Patients without renal failure (group A) often had fewer leukemic cells in the peripheral blood than patients with azotemia (group B). In nine patients, monoblasts were observed in addition to the abnormal monocytes and these cells were included in the total count of monocytes.

\section{Group A ( Tables I and II)}

Serum. By definition, patients included in this group had normal BUN, serum creatinine, and creatinine clearance. Blood urea nitrogen varied between 7 and $23 \mathrm{mg} / 100 \mathrm{ml}$ and serum creatinine ranged from 0.8 to $1.4 \mathrm{mg} / 100 \mathrm{ml}$. Creatinine clearances varied from 71 to $104 \mathrm{ml} / \mathrm{min}$. The serum uric acid was normal in all but one patient in whom a value of $12 \mathrm{mg} / 100 \mathrm{ml}$ was recorded. The serum potassium was normal in all but two patients (Nos. 4 and 5) in whom values of 3.0 and $3.2 \mathrm{mEq} /$ liter were recorded. In two patients (Nos. 5 and 6) the serum calcium was $7.6 \mathrm{mg} / 100 \mathrm{ml}$ while the serum phosphorus was normal. No other disorders of electrolytes were found. One of the patients with hypocalcemia (No. 5) also had a low serum albumin of 2.9 $\mathrm{g} / 100 \mathrm{ml}$.

The total serum protein varied from 4.67 to $9.6 \mathrm{~g} / 100$ $\mathrm{ml}$ (mean $6.84 \pm 1.33 \mathrm{~g} / 100 \mathrm{ml}$ ). In two patients, the level exceeded the normal range and in two others was below normal (normal values, Table III). The gamma globulin concentration ranged from 0.84 to $3.5 \mathrm{~g} / 100 \mathrm{ml}$ (mean $1.7 \pm 0.73$ ) with hypergammaglobulinemia in four patients. None had hypogammaglobulinemia. Im- 
TABLE I

Hematologic and Metabolic Data in Patients

\begin{tabular}{|c|c|c|c|c|c|c|c|c|}
\hline \multirow[b]{2}{*}{ No. } & \multirow[b]{2}{*}{ Patient } & \multirow[b]{2}{*}{ Sex } & \multirow[b]{2}{*}{ Age } & \multirow{2}{*}{$\begin{array}{c}\text { No. of } \\
\text { monocytes }\end{array}$} & \multirow{2}{*}{$\begin{array}{c}\text { No. of } \\
\text { polymor- } \\
\text { phonuclears }\end{array}$} & \multicolumn{3}{|r|}{ Serum } \\
\hline & & & & & & $\mathrm{K}^{*}$ & $\mathrm{Ca}^{*}$ & $P_{*}$ \\
\hline & & & $y r$ & $m m^{3}$ & $m m^{3}$ & $m E q /$ liter & & $\mathrm{mg} / 100 \mathrm{ml}$ \\
\hline 1 & A. G. & $\mathrm{M}$ & 85 & 1054 & 42.780 & 4.7 & 8.2 & 3.4 \\
\hline 2 & T. P. & $\mathbf{M}$ & 48 & $\begin{array}{c}1044 \\
(14) \ddagger\end{array}$ & 696 & 3.8 & 8.4 & 2.9 \\
\hline 3 & P. K. & $\mathrm{F}$ & 50 & $\begin{array}{l}670 \\
(67)\end{array}$ & 268 & 3.9 & 9.1 & 4.4 \\
\hline 4 & M. N. & $\mathrm{F}$ & 56 & $\begin{array}{r}2870 \\
(21)\end{array}$ & 12.095 & 3.0 & 9.1 & 3.8 \\
\hline 5 & E. B. & $\mathrm{F}$ & 69 & 6900 & 21.000 & 3.2 & 7.6 & 2.6 \\
\hline 6 & H. B. & M & 54 & 17.850 & 38.556 & 3.9 & 7.6 & 3.1 \\
\hline 7 & B. W. & $\mathrm{F}$ & 60 & 858 & 5148 & 3.8 & 8.0 & 2.9 \\
\hline 8 & L. B. & $\mathrm{F}$ & 70 & 615 & 2796 & 4.0 & 9.2 & 4.4 \\
\hline 9 & O. B. & $\mathbf{M}$ & 49 & $\begin{array}{r}2256 \\
(19)\end{array}$ & 0 & 3.7 & 8.6 & 4.2 \\
\hline Mean & & & 60.1 & 3790 & 13.704 & 3.8 & 8.4 & 3.5 \\
\hline SD & & & 11.7 & 5313 & 15.806 & 0.46 & 0.59 & 0.66 \\
\hline
\end{tabular}

$\mathrm{C}_{\mathrm{or}}=$ creatine clearance; $\mathrm{C}_{\mathrm{u} . \mathrm{a} .}=$ uric acid clearance.

* Normal values: $\mathrm{K}, 3.6-5.0 \mathrm{mEq} / \mathrm{liter} ; \mathrm{P}, 2.5-4.8 \mathrm{mg} / 100 \mathrm{ml}$; BUN, $5-25 \mathrm{mg} / 100 \mathrm{ml}$; creatinine clearance, $70-130 \mathrm{ml} / \mathrm{min}$; urinary uric acid, $250-750 \mathrm{mg} / 24 \mathrm{hr} ; \mathrm{Ca}, 8.5-10.5 \mathrm{mg} / 100 \mathrm{ml} ; \mathrm{Mg} 1.6-3.2$ $\mathrm{mg} / 100 \mathrm{ml}$; creatinine, $0.8-1.4 \mathrm{mg} / 100 \mathrm{ml}$; serum uric acid, $2.5-7.0 \mathrm{mg} / 100 \mathrm{ml}$; uric acid clearance, $5.0-12.5 \mathrm{ml} / \mathrm{min}$.

$\ddagger$ Per cent of monoblasts.

munoquantitation (See Table II) showed IgG concentrations ranging from 550 to $2400 \mathrm{mg} / 100 \mathrm{ml}$. Levels exceeding $1600 \mathrm{mg} / 100 \mathrm{ml}$ were observed in four patients. IgA concentrations varied from 100 to $2360 \mathrm{mg} /$ $100 \mathrm{ml}$ and exceeded $350 \mathrm{mg} / 100 \mathrm{ml}$ in three of the same four patients. $\operatorname{IgM}$ concentrations ranged from 35 to $322 \mathrm{mg} / 100 \mathrm{ml}$ and was clearly elevated in only one patient. Among individual cases, one patient had hypergammaglobulinemia involving all three immunoglobulins, and two patients had an increase in both IgG and IgA. In all patients, the level of IgD was either low or normal. The Sia test was positive in one patient who also had a high concentration of IgM. No cryoglobulins or pyroglobulins were found. Serum transferrin was decreased as compared to the normal controls, and varied from 48 to $224 \mathrm{mg} / 100 \mathrm{ml}$ (mean $121 \pm 44$ $\mathrm{mg} / 100 \mathrm{ml}$ ) being $150 \mathrm{mg} / 100 \mathrm{ml}$ or less in seven patients. Ceruloplasmin varied between 13.4 and $62 \mathrm{mg} /$ $100 \mathrm{ml}$ (mean $31.8 \pm 17.7$ ), and was less than $25 \mathrm{mg} / 100$ $\mathrm{ml}$ in three patients. $\alpha_{2}$-Macroglobulin ranged from 148 to $710 \mathrm{mg} / 100 \mathrm{ml}$. The level was below $200 \mathrm{mg} / 100 \mathrm{ml}$ in the sera of five patients. Serum LZM varied from 5 to $84 \mu \mathrm{g} / \mathrm{ml}$ with a mean of $31.3 \pm 16.6 \mu \mathrm{g} / \mathrm{ml}$. This range included a number of determinations obtained while patients were in remission. The LZM level was consistently increased before therapy varying from 24 to 84 $\mu \mathrm{g} / \mathrm{ml}$ with a mean of $41 \mu \mathrm{g} / \mathrm{ml}$. No direct correlation was observed between the level of serum LZM and the number of the circulating leukemic cells. In five instances, the $C^{\prime} 3$ level was recorded in the range of $116-208 \mathrm{mg} /$ $100 \mathrm{ml}$ with a mean of $156 \mathrm{mg} / 100 \mathrm{ml}$. None of the patients suffered from bacterial or other infections during the period of study. Six patients were treated with various antileukemic agents while three patients received steroids.

Urine. The total urinary protein varied from 31 to $1720 \mathrm{mg} / 24 \mathrm{hr}$ with an average of $524 \mathrm{mg} / 24 \mathrm{hr}$, and exceeded $300 \mathrm{mg}$ in five instances. Cellulose acetate electrophoresis of the urinary proteins revealed variable patterns, frequently with low contents of albumin and prominent $\alpha_{2}$ and $\beta$-proteins. In two patients, lysozyme constituted the major component excreted in the urine, the electrophoretic pattern resembling Fig. 1 a. In seven others, the electrophoretic patterns were similar to those shown in Fig. $1 b$ and $c$. Albumin constituted $1-32 \%$ of the total urinary protein, with an average of 
with Normal Renal Function (Group A)

\begin{tabular}{|c|c|c|c|c|c|c|c|}
\hline \multicolumn{4}{|l|}{ Serum } & \multirow{2}{*}{$\begin{array}{l}\text { Urine, } \\
\text { uric acid* }\end{array}$} & \multirow[b]{2}{*}{$\mathrm{C}_{\mathrm{er}}$} & \multirow[b]{2}{*}{ Cu.s. } & \multirow[b]{2}{*}{ Treatment } \\
\hline $\mathbf{M g}^{*}$ & BUN* & Creatinine* & Uric acid* & & & & \\
\hline$m g / 100 m l$ & & & & $m g / 24 \mathrm{hr}$ & $m l / m i n$ & $m l / \min$ & \\
\hline 1.80 & 21 & 1.3 & 6.7 & 744 & 82 & 8.06 & - \\
\hline 1.72 & 12 & 0.8 & 4.3 & 780 & 104 & 12.6 & $\begin{array}{l}\text { Vincristine } \\
6 \mathrm{MP}\end{array}$ \\
\hline 1.75 & 11 & 1.1 & 5.8 & 544 & 75 & 6.57 & $\begin{array}{l}\text { Prednisone } \\
6 \mathrm{MP}\end{array}$ \\
\hline 1.75 & 7 & 0.7 & 6.4 & 396 & 78 & 4.29 & $\begin{array}{l}\text { Allopurinol } \\
6 \mathrm{MP}\end{array}$ \\
\hline 1.70 & 23 & 0.6 & 3.3 & 266 & 89 & 12.1 & Prednisone \\
\hline 1.90 & 11 & 1.0 & 5.6 & 798 & 92 & 9.9 & - \\
\hline 1.70 & 9 & 0.8 & 3.4 & 596 & 71 & 12.16 & $\begin{array}{l}\text { Amethopterin } \\
6 \mathrm{MP}\end{array}$ \\
\hline 1.74 & 16 & 1.4 & 3.4 & 328 & 73 & 6.69 & $\begin{array}{l}\text { Prednisone } \\
6 \text { MP, MTX }\end{array}$ \\
\hline 1.73 & 17 & 1.0 & 12.0 & 1009 & 89 & 6.48 & $\begin{array}{l}\text { Vincristine } \\
6 \mathrm{MP} \\
\text { Allopurinol }\end{array}$ \\
\hline 1.75 & 14 & 0.97 & 5.7 & 606 & 83.7 & 8.77 & \\
\hline 0.06 & 5.1 & 0.25 & 2.6 & 232 & 10.1 & 2.85 & \\
\hline
\end{tabular}

$12.8 \pm 5.7 \%$. The amount of IgG excreted ranged from 6.8 to $364 \mathrm{mg} / 24 \mathrm{hr}$. Clearances of IgG varied greatly but were approximately 7 times higher than in healthy controls. Excretion of $\operatorname{IgA}$ varied from 1.1 to 111.0 $\mathrm{mg} / 24 \mathrm{hr}$. In one instance, the amount of $\mathrm{IgA}$ excreted exceeded that of IgG in the urine. In the remainder, the ratios of IgG to IgA varied from $2: 1$ to $30: 1$. Clearances of $\operatorname{IgA}$ also showed great variations, and were approximately 4 times higher than in healthy individuals. IgD and IgM were detected in only one urine each. $\mathrm{Fc}$ and $\mathrm{F}^{\prime} \mathrm{c}$ fragments of $\mathrm{IgG}$ were detected in the urines of five patients. This observation bore no relationship to the storage time of the urine since these fragments were observed in three completely fresh urines. In one instance transitory excretion of Bence Jones type kappa protein was noted.

Transferrin was excreted in amounts varying from 0 to $33.6 \mathrm{mg} / 24 \mathrm{hr}$ and comprised up to $37 \%$ of the total urinary protein with a mean of $1.34 \%$. The average clearance of transferrin was approximately twice as high as in healthy persons although a great variability in individual clearances was observed.
Ceruloplasmin varied from 0.78 to $8.65 \mathrm{mg} / 24 \mathrm{hr}$, and accounted for $0.09-9.6 \%$ of the total urinary protein with a mean of $0.43 \%$. The mean clearance was similar to that in normal controls.

$\alpha_{2}$-Macroglobulin was excreted in the urines of four patients in amounts varying from 0.87 to $13.54 \mathrm{mg} / 24$ hr. This protein was not found in the urines of nine healthy persons. The $\mathrm{C}^{\prime} 3$ level was tested in five urines and detected in one only in the amount of $8.5 \mathrm{mg} / 24 \mathrm{hr}$.

Lysozyme excretion varied greatly from $0.9 \mathrm{mg}$ to $1320 \mathrm{mg} / 24 \mathrm{hr}$ (mean 142.5). This range included values obtained during remissions. Pretreatment values were always higher with an average excretion of 239 $\mathrm{mg} / 24 \mathrm{hr}$. (The maximum excretion of LZM in the urines of healthy persons never exceeded $2.9 \mathrm{mg} / 24 \mathrm{hr}$.) Lysozyme constituted from 1 to $47.2 \%$ of the total urinary protein, with an average of $9.4 \%$. Renal clearances of LZM varied greatly, being in the normal range in 12 instances and increased in 18 others. A correlation coefficient $(r)$ of a linear function was calculated for the serum and urinary LZM levels and also for the serum LZM and Clzm. In the first instance, the correla- 
TABLE II

Protein Studies in Patients with

\begin{tabular}{|c|c|c|c|c|c|c|c|c|c|c|c|c|c|}
\hline \multirow[b]{2}{*}{ No. } & \multicolumn{2}{|c|}{ Serum } & \multicolumn{2}{|c|}{ Urine } & \multicolumn{3}{|c|}{ Lysozyme } & \multicolumn{3}{|c|}{ Transferrin } & \multicolumn{3}{|c|}{ Ceruloplasmin } \\
\hline & $\begin{array}{l}\text { Total } \\
\text { protein }\end{array}$ & $\begin{array}{l}\text { Gamma } \\
\text { globulin }\end{array}$ & $\begin{array}{c}\text { Total } \\
\text { protein }\end{array}$ & Albumin & Serum & Urine & Clearance & Serum & Urine & Clearance & Serum & Urine & Clearance \\
\hline & \multicolumn{2}{|c|}{$\mathrm{g} / 100 \mathrm{ml}$} & $\begin{array}{c}g / 24 \\
h r\end{array}$ & $\begin{array}{c}\% \text { of } \\
\text { total } \\
\text { protein }\end{array}$ & $\mu g / m l$ & $\begin{array}{c}m g / 24 \\
h r\end{array}$ & $m l / \min$ & $\begin{array}{c}m g / 100 \\
m l\end{array}$ & $\begin{array}{c}m g / 24 \\
h r\end{array}$ & $m l / m i n$ & $\begin{array}{c}m g / 100 \\
m l\end{array}$ & $\begin{array}{c}m g / 24 \\
h r\end{array}$ & $m l / m i n$ \\
\hline 1 & 5.60 & 1.52 & 0.440 & 9 & 38 & 15.4 & 0.28 & 91 & 9.02 & 0.007 & 13.4 & 3.52 & 0.018 \\
\hline 2 & 6.78 & 1.07 & 0.095 & 32 & 27.4 & 0.95 & 0.024 & 152 & 1.25 & 0.0006 & 26.2 & 0.78 & 0.002 \\
\hline 3 & 6.50 & 1.65 & 0.192 & 15 & 34 & 7.15 & 0.146 & 48 & 1.70 & 0.0024 & 62.0 & 1.36 & 0.0015 \\
\hline 4 & 6.47 & 1.43 & 0.052 & 13 & 38.5 & 15.4 & 0.28 & 150 & 2.53 & 0.0018 & 41.0 & 1.35 & 0.0023 \\
\hline 5 & 9.60 & 3.50 & 0.031 & 14 & 36.0 & 20.2 & 0.39 & 224 & 33.6 & 0.010 & 57.0 & 8.65 & 0.011 \\
\hline 6 & 8.15 & 2.18 & 0.570 & 8 & $\begin{array}{l}43 \\
84\end{array}$ & $\begin{array}{r}269 \\
1320\end{array}$ & $\begin{array}{c}4.34 \\
21.3\end{array}$ & 116 & 1.89 & 0.0011 & 41.0 & 2.30 & 0.004 \\
\hline 7 & 4.67 & 0.84 & 1.140 & 7 & $\begin{array}{l}24 \\
13.2\end{array}$ & $\begin{array}{l}65 \\
16.6\end{array}$ & $\begin{array}{l}1.89 \\
0.87\end{array}$ & 124 & 4.21 & 0.0024 & 56.0 & 2.17 & 0.0027 \\
\hline 8 & 6.73 & 1.42 & 1.720 & 16 & 34.0* & $\begin{array}{l}0.9- \\
45.7\end{array}$ & $\begin{array}{l}0.03- \\
0.93\end{array}$ & 123 & 1.27 & 0.0007 & 17.0 & 1.47 & 0.006 \\
\hline 9 & 7.05 & 1.66 & 0.48 & 1 & $\begin{array}{c}5.0- \\
53.0 \ddagger\end{array}$ & $\begin{array}{c}1.46- \\
693\end{array}$ & $\begin{array}{c}0.06- \\
11.47\end{array}$ & $61-149$ & $0-7.95$ & $0-0.0049$ & $\begin{array}{l}14.8- \\
19.6\end{array}$ & $\begin{array}{l}0.80- \\
2.60\end{array}$ & $\begin{array}{l}0.0028- \\
0.012\end{array}$ \\
\hline Mean & 6.84 & 1.70 & 0.524 & 12.8 & 31.3 & 142.5 & 2.53 & 121 & $\begin{array}{l}5.61 \\
8.87\end{array}$ & $\begin{array}{l}0.00279 \\
0.00293\end{array}$ & $\begin{array}{l}31.8 \\
17.7\end{array}$ & $\begin{array}{l}2.43 \\
2.02\end{array}$ & $\begin{array}{l}0.0066 \\
0.0049\end{array}$ \\
\hline SD & 1.33 & 0.73 & 0.535 & 5.7 & 16.6 & 277.1 & 4.51 & 44 & 8.87 & 0.00293 & 17.7 & 2.02 & 0.0049 \\
\hline
\end{tabular}

All these were included in the calculation of the mean value and standard deviation.

* 7 sets of estimations.

$\$ 14$ sets of estimations.

tion was significant at the level of $P<0.02$ and in the second, at $P<0.025$ (Figs. 2 and 3 ).

An analysis of the relationship between the level of serum LZM and the amount of urinary LZM revealed three patterns. In 21 instances, both values were proportionally high. Four estimations showed increased serum LZM and normal level of the enzyme in the urine. In these patients, the serum LZM concentration varied from 21.3 to $34 \mu \mathrm{g} / \mathrm{ml}$ and the urinary LZM ranged from 0.48 to $1.97 \mu \mathrm{g} / \mathrm{ml}$. In five instances, serum LZM was dysproportionally low as compared to the urinary LZM. The serum values varied from 6.5 to $28.7 \mu \mathrm{g} / \mathrm{ml}$ while the urinary LZM values ranged from 4.1 to 242 $\mu \mathrm{g} / \mathrm{ml}$. In 16 instances, urinary LZM was high although serum LZM level was increased less than three times as compared to maximum normal value. Here the serum LZM varied from 6.5 to $43 \mu \mathrm{g} / \mathrm{ml}$ with a mean of 29.2 $\mu \mathrm{g} / \mathrm{ml}$, whereas urinary LZM ranged from 4.1 to 242 $\mu \mathrm{g} / \mathrm{ml}$ with a mean of $74 \mu \mathrm{g} / \mathrm{ml}$.

Investigation of selectivity of protein excretion showed that ratios of $\mathrm{C}_{\mathrm{Ig}} / \mathrm{C}_{\mathrm{Tr}}$ varied from 5.4 to 772 and were below 100 in only five instances. In four patients, the ratios of $\mathrm{C} \alpha-2 \mathrm{M} / \mathrm{C}_{\text {тr }}$ varied from 3.5 to 89 . Five patients showed no $\alpha_{2}$-macroglobulin in the urine.
None of the individual cases showed high selectivity pattern.

Uric acid excretion was normal in all but three patients, one with hyperuricemia and two with normal serum uric acid level.

The kidneys of three patients (Nos. 2, 4, and 5) were available for histological study. All three showed a moderate number of protein casts in the collecting tubules. In two, there were small interstitial leukemic infiltrates and in one, occasional hyalinization of the glomeruli. In one patient (No. 5) there were many hyaline droplets in the proximal tubular cells. This patient had a moderately high level of urinary LZM $(20 \mu \mathrm{g} / \mathrm{ml})$ and a very high level of serum gammaglobulins $(3.5 \mathrm{~g} / 100 \mathrm{ml})$. Hypokalemia and hypocalcemia were additional findings. None of the three patients had excessive uricosuria or hyperuricemia and none suffered from intercurrent infection.

\section{Group B ( Tables IV and V)}

Serum. In this group, the blood urea nitrogen varied between 8 and $150 \mathrm{mg} / 100 \mathrm{ml}$. However, in every patient the level exceeded $30 \mathrm{mg} / 100 \mathrm{ml}$ during $2 \mathrm{wk}$ immediately preceding or following the date of serum and urinary collections. The serum creatinine was in- 
Normal Renal Function (Group A)

\begin{tabular}{|c|c|c|c|c|c|c|c|c|c|c|c|c|c|c|c|}
\hline \multicolumn{3}{|c|}{ IgG } & \multicolumn{3}{|c|}{$\operatorname{IgA}$} & \multicolumn{3}{|c|}{ IgD } & \multicolumn{3}{|c|}{ IgM } & \multicolumn{3}{|c|}{$\alpha$-Macroglobulin } & \multirow[t]{2}{*}{ Comments } \\
\hline Serum & Urine & $\begin{array}{l}\text { Clear- } \\
\text { ance }\end{array}$ & Serum & Urine & $\begin{array}{l}\text { Clear- } \\
\text { ance }\end{array}$ & Serum & Urine & $\begin{array}{l}\text { Clear- } \\
\text { ance }\end{array}$ & Serum & Urine & $\begin{array}{l}\text { Clear- } \\
\text { ance }\end{array}$ & Serum & Urine & $\begin{array}{l}\text { Clear- } \\
\text { ance }\end{array}$ & \\
\hline $\begin{array}{c}m g / \\
100 m l\end{array}$ & $\begin{array}{l}m g / \\
24 h r\end{array}$ & $\begin{array}{l}m l / \\
\min \end{array}$ & $\begin{array}{l}m g / \\
100 m l\end{array}$ & $\begin{array}{l}m g / \\
24 h r\end{array}$ & $\begin{array}{l}m l / \\
\min \end{array}$ & $\begin{array}{c}m g / \\
100 m l\end{array}$ & $\begin{array}{l}m g / \\
24 h r\end{array}$ & $\begin{array}{l}m l / \\
\min \end{array}$ & $\begin{array}{l}m g / \\
100 \mathrm{ml}\end{array}$ & $\begin{array}{l}m g / \\
24 h r\end{array}$ & $\begin{array}{l}m l / \\
\min \end{array}$ & $\begin{array}{l}m g / \\
100 \mathrm{ml}\end{array}$ & $\begin{array}{l}m g / \\
24 h r\end{array}$ & $\begin{array}{l}m l / \\
\min \end{array}$ & \\
\hline 2150 & 121 & 0.0039 & 420 & 18.7 & 0.0031 & $2<$ & $\mathbf{0}$ & - & 50 & 0 & 0 & 151 & 13.54 & 0.0062 & $\begin{array}{l}\text { Fc and F'c fragments } \\
\text { in the urine }\end{array}$ \\
\hline 1380 & 7.2 & 0.00036 & 186 & 3.60 & 0.0013 & 9.2 & $\mathbf{0}$ & - & 110 & $\mathbf{0}$ & 0 & 260 & $\mathbf{0}$ & $\mathbf{0}$ & - \\
\hline 1260 & 20.4 & 0.0011 & 175 & 6.80 & 0.0027 & 5.1 & $\mathbf{0}$ & - & 100 & 0 & $\mathbf{0}$ & 355 & 4.42 & 0.00086 & $\begin{array}{l}\text { Fc and F'c fragments } \\
\text { in the urine }\end{array}$ \\
\hline 1430 & 24.8 & 0.0012 & 340 & 3.85 & 0.00079 & $2<$ & 0 & - & 60 & 0 & $\mathbf{0}$ & 197 & 0 & $\mathbf{0}$ & - \\
\hline 2400 & 20.2 & 0.00054 & 2360 & 26.26 & 0.00070 & 6.5 & $\mathbf{0}$ & - & 322 & 0 & $\mathbf{0}$ & 175 & 0.87 & 0.00035 & $\begin{array}{l}\text { Sia test }+; F c \text { and } \\
\text { F'c fragments in } \\
\text { the urine }\end{array}$ \\
\hline 1730 & 212 & 0.0085 & 430 & 7.33 & 0.0012 & $2<$ & 0 & - & 53 & 0 & 0 & 148 & $\mathbf{0}$ & $\mathbf{0}$ & $\begin{array}{l}\text { Fc and F'c fragments } \\
\text { in the urine }\end{array}$ \\
\hline $\mathbf{5 5 0}$ & 34.2 & 0.0052 & 100 & 2.51 & 0.0020 & $2<$ & 5.2 & - & 35 & 5.7 & 0.013 & 710 & 3.99 & 0.00039 & - \\
\hline 960 & 6.8 & 0.00078 & 125 & 1.13 & 0.0010 & $2<$ & 0 & - & 140 & 0 & 0 & 160 & 0 & 0 & $\begin{array}{l}\text { Fc and } F^{\prime} c \text { fragments } \\
\text { in the urine }\end{array}$ \\
\hline 1730 & 364 & 0.0099 & 260 & 111.0 & 0.0020 & $2<$ & 0 & - & 137 & 0 & 0 & 265 & 0 & 0 & $\begin{array}{l}\text { Transitory excretion } \\
\text { of Bence Jones } \\
\text { type kappa globu- } \\
\text { lin in the urine }\end{array}$ \\
\hline 1510 & 90.1 & 0.0035 & 488 & 20.13 & 0.0016 & - & - & - & 112 & - & - & 269 & - & - & \\
\hline 538 & 116.3 & 0.0034 & 671 & 33.08 & 0.0008 & - & - & - & 83 & - & 一 & 169 & - & - & \\
\hline
\end{tabular}

creased in three patients and creatinine clearances were lower than normal in seven. The serum uric acid varied from 3.0 and $17.9 \mathrm{mg} / 100 \mathrm{ml}$ and exceeded $7.5 \mathrm{mg} / 100$

$\mathrm{ml}$ in three patients. Serum potassium was repeatedly low in three patients (Nos. 1, 4, and 7) varying between 2.2 and $3.4 \mathrm{mEq} /$ liter. In two of these, the

TABLE III

Protein Studies in Healthy Individuals

\begin{tabular}{|c|c|c|c|c|c|c|c|c|c|c|}
\hline \multirow[b]{2}{*}{ Protein } & \multirow{2}{*}{$\begin{array}{c}\text { No. of } \\
\text { cases }\end{array}$} & \multicolumn{3}{|c|}{ Serum } & \multicolumn{3}{|c|}{ Urine } & \multicolumn{3}{|c|}{ Clearance } \\
\hline & & Range & Mean & SD & Range & Mean & sD & Range & Mean & SD \\
\hline & & \multicolumn{3}{|c|}{$m g / 100 \mathrm{ml}$} & \multicolumn{3}{|c|}{$m g / 24 \mathrm{hr}$} & \multicolumn{3}{|c|}{$m l / m i n$} \\
\hline Lysozyme* & 20 & $6.6-13.8$ & 9.69 & 1.80 & $7.6-2900$ & 1570 & 800 & $0.005-0.33$ & 0.116 & 0.071 \\
\hline Transferrin & 9 & $160-276$ & 219 & 37 & $2.07-7.31$ & 3.61 & 1.88 & $\begin{array}{l}0.00072- \\
0.0023\end{array}$ & 0.0012 & 0.0006 \\
\hline Ceruloplasmin & 9 & $23.5-41.0$ & 30.2 & 5.1 & $0.69-4.33$ & 2.68 & 1.26 & $\begin{array}{l}0.0013- \\
0.012\end{array}$ & 0.0064 & 0.0034 \\
\hline IgG & 10 & $980-1530$ & 1278 & 227 & $12.6-112$ & 53.62 & 40.7 & $\begin{array}{l}0.00019- \\
0.00061\end{array}$ & 0.00046 & 0.00014 \\
\hline $\operatorname{Ig} A$ & 10 & $204-322$ & 259 & 45 & $0-3.36$ & 2.3 & 1.25 & $0-0.0011$ & 0.00045 & 0.00037 \\
\hline$\alpha_{2}$-Macroglobulin & $\begin{array}{l}9 \\
9\end{array}$ & - & $\begin{array}{l}372 \ddagger \\
355\end{array}$ & 一 & $0 \S$ & 0 & $\mathbf{0}$ & 0 & 0 & 0 \\
\hline $\operatorname{Ig} M$ & 10 & $63-165$ & 93 & 38 & 0 & 0 & 0 & 0 & 0 & 0 \\
\hline
\end{tabular}

Serum total protein, normal range $6.3-8.0 \mathrm{~g} / 100 \mathrm{ml}$; serum gamma globulin, normal range $0.7-1.6 \mathrm{~g} / 100 \mathrm{ml}$; urinary total protein, normal range 50-187 mg/24 hr; IgD, 'normal range 0.3-40/mg/100 ml (57).

* Serum level in $\mu \mathrm{g} / \mathrm{ml}$, daily excretion in $\mu \mathrm{g} / 24 \mathrm{hr}$.

$\ddagger$ Pooled serum samples of nine women and nine men.

$\S$ Nine individual estimations. 

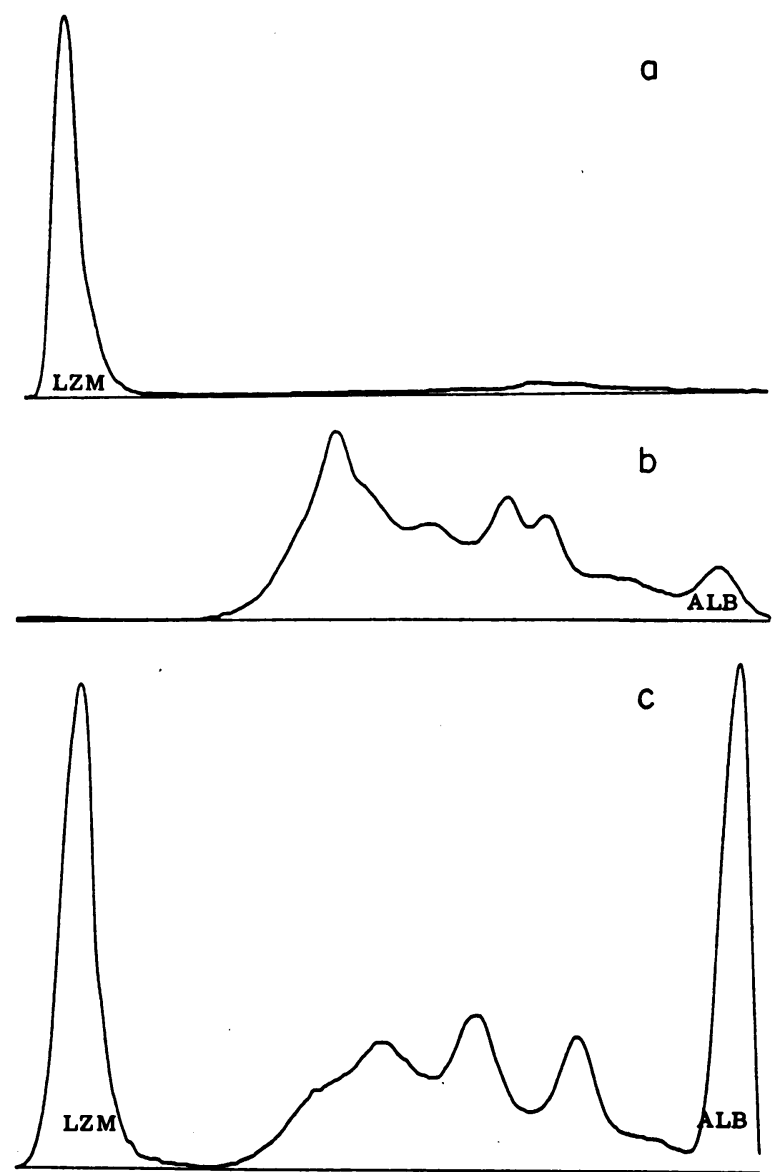

FIGURE 1 Representative electrophoretic patterns of concentrated urine of patients with mono- and myelomonocytic leukemia. (a) Lysozyme is the major protein excreted. $\mathrm{Pa}-$ tient 8 , group B: BUN, $48 \mathrm{mg} / 100 \mathrm{ml} ; \mathrm{K}, 2.9 \mathrm{mEq} /$ liter; proteinuria $1.26 \mathrm{~g} / 24 \mathrm{hr}$; lysozymuria $1.19 \mathrm{~g} / 24 \mathrm{hr}$. (b) Predominant excretion of $\alpha$ - and $\beta$-proteins. Patient 6, group B: BUN, $150 \mathrm{mg} / 100 \mathrm{ml} ; \mathrm{K}, 3.4 \mathrm{mEq} / \mathrm{liter}$; proteinuria $6.24 \mathrm{~g} / 24 \mathrm{hr}$; lysozymuria $18 \mathrm{mg} / 24 \mathrm{hr}$. (c) Albumin and globulins, and lysozyme excreted in large quantities. Patient 4, group B: BUN, $77 \mathrm{mg} / 100 \mathrm{ml}$; $\mathrm{K}, 3.3$ $\mathrm{mEq} /$ liter; proteinuria $3.26 \mathrm{~g} / 24 \mathrm{hr}$; lysozymuria 298 $\mathrm{mg} / 24 \mathrm{hr}$.

calcium was also low $(7.4$ and $7.7 \mathrm{mg} / 100 \mathrm{ml}$ ) with a low serum phosphorus and magnesium in one patient. The latter patient had hypoalbuminemia of $2.8 \mathrm{~g} / 100$ $\mathrm{ml}$ and suffered from chronic pyelonephritis in addition to leukemia. In two other patients (Nos. 6 and 8) a single estimation also showed hypokalemia.

The total serum protein varied from 5.6 to $8.5 \mathrm{~g} / 100$ $\mathrm{ml}$ (mean $7.14 \pm 0.84 / 100 \mathrm{ml}$ ). It was in excess of normal in one patient, and below the normal range in two. Gamma globulin ranged from 0.90 to $3.67 \mathrm{~g} / 100 \mathrm{ml}$ (mean $2.26 \pm 0.84 \mathrm{~g} / 100 \mathrm{ml}$ ). The level exceeded the upper normal limit in seven patients. None were subnormal.
Immunoquantitation of IgG (see Table V) showed values from 930 to $3200 \mathrm{mg} / 100 \mathrm{ml}$, the level exceeding $1600 \mathrm{mg} / 100 \mathrm{ml}$ in eight patients. IgA levels varied from 106 to $1870 \mathrm{mg} / 100 \mathrm{ml}$ and exceeded $350 \mathrm{mg} / 100$ $\mathrm{ml}$ in seven patients. $\operatorname{IgD}$ was normal or low. IgM ranged from 36 to $685 \mathrm{mg} / 100 \mathrm{ml}$ and exceeded 200 $\mathrm{mg} / 100 \mathrm{ml}$ in seven patients. Seven patients showed an increase in all three immunoglobulins, and one an increase in IgG and IgA only. The Sia test was positive in four patients who also had high levels of macroglobulin. One patient had cryoglobulin in the serum and Bence Jones proteinuria.

Transferrin levels varied from 89 to $289 \mathrm{mg} / 100 \mathrm{ml}$ with values below $150 \mathrm{mg} / 100 \mathrm{ml}$ in four patients. Three patients suffered from bacterial infection during the study (Nos. 1, 7, and 9), requiring treatment with antibiotics. The gammaglobulins were reduced in one of these and increased in two. Transferrin was 173, 176, and $263 \mathrm{mg} / 100 \mathrm{ml}$, respectively.

Ceruloplasmin ranged from 22.4 to $100 \mathrm{mg} / 100 \mathrm{ml}$ and was less than $25 \mathrm{mg} / 100 \mathrm{ml}$ in one serum only. $\alpha_{2}$-Macroglobulin varied from 130 to $370 \mathrm{mg} / 100 \mathrm{ml}$. In four patients, the level was low $(200 \mathrm{mg} / 100 \mathrm{ml}$ or less). Serum LZM varied from 28.2 to $150 \mu \mathrm{g} / \mathrm{ml}$ with a mean of $85 \pm 36.8 \mu \mathrm{g} / \mathrm{ml}$. C'3 was estimated in three cases and varied from 100 to $254 \mathrm{mg} / 100 \mathrm{ml}$.

Urine. The total protein excreted in the urine ranged from 0.83 to $6.64 \mathrm{~g} / 24 \mathrm{hr}$ (mean $3.1 \pm 2.04 \mathrm{~g}$ ).

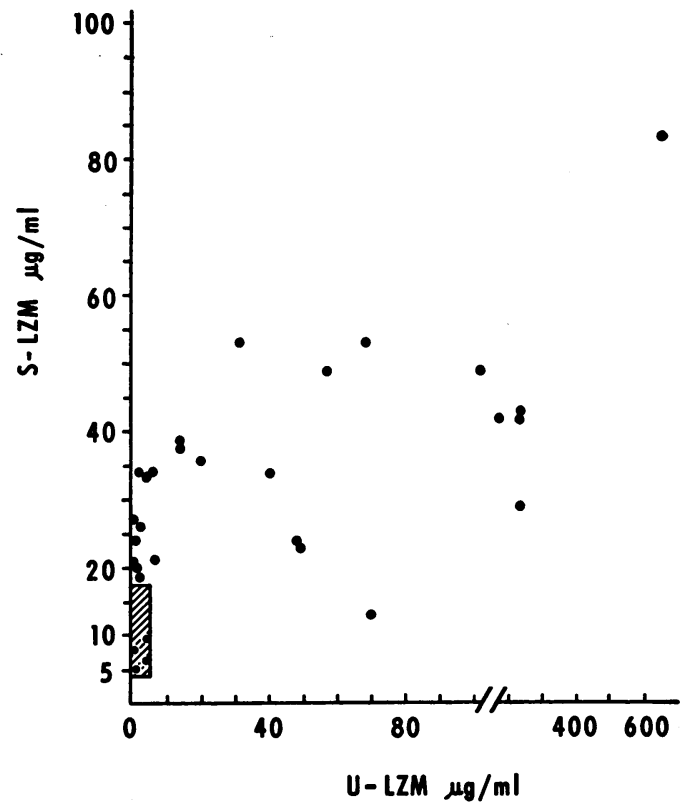

Figure 2 Group A. Relationship between serum lysozyme (S-LZM) and urinary lysozyme (U-LZM), 30 estimations. $r^{2}=0.4597$. Correlation significant at the level $P<0.02$. Shaded area indicates normal range. 


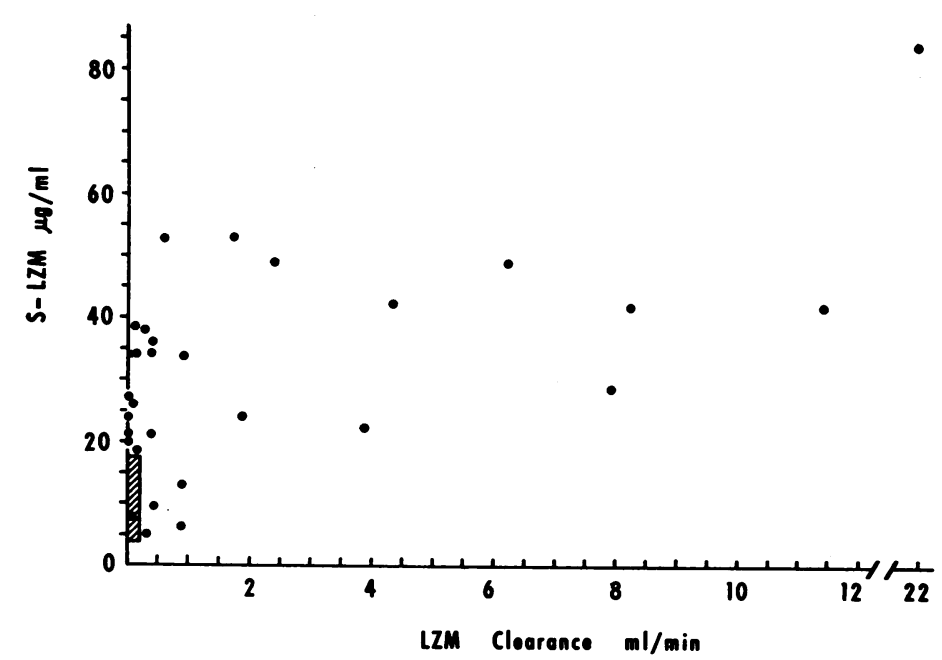

FIGURE 3 Group A. Relationship between serum lysozyme (S-LZM) and its clearance by the kidneys, 30 estimations. $r^{2}=0.42230$. Correlation significant at the level $P<0.025$. Shaded area indicates normal range.

Cellulose acetate electrophoresis of the urinary proteins revealed lysozyme as the predominant constituent in three patients with a pattern resembling Fig. $1 a$. In the remainder, the patterns were similar to those in Fig. $1 b$ and $c$. Albumin, expressed as a percentage of the total protein excreted in the urine, ranged from 3 to $33 \%$ (mean $18 \pm 9.9 \%$ ) being less than $25 \%$ in seven patients. IgG ranged from 6.8 to $445 \mathrm{mg} / 24 \mathrm{hr}$ and $\mathrm{IgA}$ from 3.75 to $228 \mathrm{mg} / 24 \mathrm{hr}$. A great variability was noted in the renal clearances of both $\operatorname{IgG}$ and $\operatorname{IgA}$. $\operatorname{IgD}$ was found in five instances ranging from 2.5 to $146 \mathrm{mg}$ in $24 \mathrm{hr}$. IgM was found in urines of five patients, varying from 0.9 to $257 \mathrm{mg} / 24 \mathrm{hr}$. Fc and $\mathrm{F}^{\prime} \mathrm{c}$ fragments of IgG were found in urines of seven patients. The Bence Jones heat test was positive in the urine of one patient.

Transferrin levels ranged from 5.25 to $52.5 \mathrm{mg} / 24 \mathrm{hr}$, and accounted for 0.08 to $4.4 \%$ of the total protein (mean $0.6 \%$ ). Ceruloplasmin ranged from 0.59 to 50.4 $\mathrm{mg} / 24 \mathrm{hr}$ with a great variability in the renal clearances and urinary concentrations. Ceruloplasmin accounted for $0.015-0.62 \%$ of the urinary protein (mean $0.16 \%) . \alpha_{2}$-Macroglobulin was found in urines of eight patients varying from 3.15 to $38.84 \mathrm{mg} / 24 \mathrm{hr}$ (mean $15.06 \mathrm{mg} / 24 \mathrm{hr}$ ). $\mathrm{C}^{\prime} 3$ was determined in three urines and varied from 0.176 to $0.648 \mathrm{mg} / 100 \mathrm{ml}$ with a total excretion of 0.29 to $9.7 \mathrm{mg} / 24 \mathrm{hr}$.

Urinary LZM values ranged from 14 to $1480 \mu \mathrm{g} / \mathrm{ml}$. The total amount in individual urines was high, reaching values up to $2 \mathrm{~g} / 24 \mathrm{hr}$. Lysozyme constituted from 0.3 to $94 \%$ of the total protein excreted (mean $23 \%$ ). In all but one instance these were high levels of serum and urinary LZM. One patient had a relatively low serum
LZM $(28.2 \mu \mathrm{g} / \mathrm{ml})$ and high urinary LZM $(14.0 \mu \mathrm{g} /$ $\mathrm{ml}$ ). Since the number of circulating monocytes and the levels of serum LZM were greater in patients of group $B$, a correlation of the levels of serum LZM to urinary LZM was determined to check whether the number of circulating monocytes was the only factor responsible for the increased excretion of LZM. The correlation coefficient $(r)$ of a linear function for serum level of LZM and urinary LZM was significant at $P<0.05$ and for serum LZM and $C_{L Z M}$ there was no statistically significant relationship (see Figs. 4 and 5). The calculation of $\mathrm{C}_{\mathrm{Ig}} / \mathrm{C}_{\mathrm{Tr}}$ and $\mathrm{C} \alpha_{2}-\mathrm{M} / \mathrm{C}_{\mathrm{Tr}}$ ratios showed variations from 8.4 to 2136 for the former and from 0 to 1905 for the latter. In one instance only was the so-called high selectivity pattern observed.

Uric acid excretion was normal in all but two patients, both with hyperuricemia.

The kidneys of three patients were examined histologically (Nos. 6, 7, and 8). In two patients (Nos. 6 and 8 ) there were protein casts in the tubules and small interstitial leukemic infiltrates. In patient 6 , red blood cells were also present in the tubules and some glomeruli showed epithelial crescents. In this instance, LZM excretion was only moderate, but proteinuria was prominent and there was hypergammaglobulinemia. In patient 8, lysozymuria was prominent and there was moderate proteinuria. Both had hypokalemia. No uric acid abnormalities were observed in either. In one patient (No. 7) there was severe tubular degeneration with hyaline droplets in the proximal tubular cells. Many casts were found in the tubules. There were also some inflammatory changes compatible with chronic pyelonephritis. This patient had markedly elevated serum 
TABLE IV

Hematologic and Metabolic Data in Patients

\begin{tabular}{|c|c|c|c|c|c|c|c|c|}
\hline \multirow[b]{2}{*}{ No. } & \multirow[b]{2}{*}{ Patient } & \multirow[b]{2}{*}{ Sex } & \multirow[b]{2}{*}{ Age } & \multirow{2}{*}{$\begin{array}{l}\text { No. of } \\
\text { monocytes }\end{array}$} & \multirow{2}{*}{$\begin{array}{l}\text { No. of } \\
\text { polymorpho- } \\
\text { nuclears }\end{array}$} & \multicolumn{3}{|r|}{ Serum } \\
\hline & & & & & & $\mathrm{K}$ & $\mathrm{Ca}$ & $\mathbf{P}$ \\
\hline & & & $y r$ & $m m^{3}$ & $m m^{8}$ & $m E q /$ liter & & $\mathrm{mg} / 100 \mathrm{ml}$ \\
\hline $1^{*}$ & L. L. & $\mathrm{F}$ & 53 & $\begin{array}{r}96,480 \\
(44) \ddagger\end{array}$ & 21,960 & 2.2 & 7.7 & 4.5 \\
\hline 2 & T. N. & $\mathbf{M}$ & 76 & 570 & 1,920 & 6.5 & 8.8 & 4.1 \\
\hline 3 & A. L. & $\mathrm{M}$ & 41 & $\begin{array}{l}6,400 \\
(20)\end{array}$ & 8,800 & 4.0 & 9.5 & 3.6 \\
\hline 4 & H. R. & M & 72 & 72,880 & 38,440 & 3.3 & 8.6 & 3.9 \\
\hline 5 & A. $\mathrm{G}$. & M & 85 & 610 & 3,100 & 4.4 & 8.7 & 3.4 \\
\hline 6 & L. G. & $\mathrm{F}$ & 69 & 4,700 & 8,580 & 3.4 & 8.1 & 2.5 \\
\hline $7 \|$ & G. M. & $\mathrm{F}$ & 80 & $\begin{array}{c}5,880 \\
(2)\end{array}$ & 1,680 & 2.2 & 7.4 & 1.1 \\
\hline 8 & D. T. & $\mathbf{M}$ & 58 & $\begin{array}{c}3,740 \\
(7)\end{array}$ & 2,450 & 2.9 & 8.9 & 4.0 \\
\hline $9^{*}$ & T. T. & M & 68 & $\begin{array}{c}17,780 \\
(3)\end{array}$ & 4,680 & 3.7 & 8.6 & 3.7 \\
\hline Mean & & & 66.9 & 23,227 & 10,179 & 3.6 & 8.6 & 3.4 \\
\hline SD & & & 13.1 & 33,653 & 12,361 & 1.2 & 0.6 & 0.97 \\
\hline
\end{tabular}

* Patients 1 and 9 had bronchopneumonia.

$\ddagger$ Per cent of monoblasts.

\& In a few days BUN increased to $32 \mathrm{mg} / 100 \mathrm{ml}$.

|| Patient 7 had chronic pyelonephritis.

gammaglobulins, pronounced lysozymuria, persistent hypokalemia, low serum calcium, phosphorus, and magnesium. No hyperuricemia was recorded.

In addition to the kidneys of six patients from the present series, renal tissue was also available from seven other patients with mono- or myelomonocytic leukemia. All seven had azotemia with hyperuricemia in three. Proteinuria was recorded in three patients. Significant histological findings included protein casts in the tubules and focal leukemic infiltrates of variable degree in six cases. Two patients also showed severe hyaline droplet degeneration of the proximal tubular cells. The serum LZM was high in both patients (42 and 113 $\mu \mathrm{g} / \mathrm{ml}$ ). The kidneys of one patient with hyperuricemia of $14.2 \mathrm{mg} / 100 \mathrm{ml}$ contained crystals in the collecting tubules. Occasional hyalinization of the glomeruli was observed in three instances and thickening of the basement membranes in one patient.

\section{DISCUSSION}

Hypogammaglobulinemia is recognized as an important feature in leukemia, especially in acute and chronic lymphocytic types $(1,3,25-27)$. In contrast, studies in patients with mono- and myelomonocytic leukemia have revealed significant hypergammaglobulinemia, affecting particularly IgG and IgA $(5,7,15)$.

In our series, serum IgG and $\operatorname{IgA}$ were increased in 12 patients and IgM was increased in 8 patients. In general, the increase was greater in patients with renal failure. There was no increase in IgD. Only 2 of 18 patients had acute intercurrent infection, while one had chronic pyelonephritis. Hypergammaglobulinemia was evident in two of the three patients while one had hypogammaglobulinemia. The remaining 15 patients showed no evidence of increased susceptibility to infections. It would appear, therefore, that the increased levels of gammaglobulins were not attributable to chronic infection. Thus far, no suitable explanation for the hypergammaglobulinemia has been forthcoming. The observation that some patients may have homogeneous M-components in the serum $(5-7,28,29)$ while a few may excrete Bence Jones globulin in the urine may be significant, giving rise to speculations concerning the possible relationship of monocytic to plasmacytic dyscrasia $(5,29)$. In this regard, it should be noted that there was no correlation between the number of circu- 
with Impaired Renal Function (Group B)

\begin{tabular}{|c|c|c|c|c|c|c|c|}
\hline \multicolumn{4}{|l|}{ Serum } & \multirow{2}{*}{$\begin{array}{l}\text { Urine, } \\
\text { uric acid }\end{array}$} & \multirow[b]{2}{*}{ Cor } & \multirow[b]{2}{*}{ Cu.s. } & \multirow[b]{2}{*}{ Treatment } \\
\hline $\mathbf{M g}$ & BUN & Creatinine & Uric acid & & & & \\
\hline$m g / 100 m l$ & & & & $m g / 24 h r$ & $m l / m i n$ & $m l / m i n$ & \\
\hline 2.25 & $8 \S$ & 2.1 & 17.9 & 803 & 33 & 3.24 & $\begin{array}{c}\text { Vincristine } \\
6 \mathrm{MP}\end{array}$ \\
\hline 1.42 & 39 & 2.2 & 7.1 & 530 & 51 & 5.25 & $\begin{array}{l}\text { Chlorambucil } \\
\text { Allopurinol }\end{array}$ \\
\hline 1.50 & 35 & 1.0 & 4.0 & 360 & 41 & 6.25 & $\begin{array}{l}\text { Vincristine } \\
6 \mathrm{MP}\end{array}$ \\
\hline 1.30 & 77 & 1.4 & 3.0 & 483 & 39 & 10.82 & $\begin{array}{c}\text { Vincristine } \\
6 \mathrm{MP}\end{array}$ \\
\hline 1.42 & 36 & 2.0 & 7.8 & 333 & 31 & 2.96 & - \\
\hline 1.86 & 150 & 0.7 & 6.2 & 520 & 82 & 5.82 & $\begin{array}{l}\text { Prednisone, } \\
6 \mathrm{MP} \\
\text { Allopurinol }\end{array}$ \\
\hline 0.86 & 28 & 1.2 & 5.4 & 584 & 42 & 7.50 & Myleran \\
\hline 1.88 & 48 & 1.4 & 7.1 & 705 & 77 & 7.21 & $\begin{array}{c}\text { Vincristine } \\
6 \mathrm{MP}\end{array}$ \\
\hline 1.87 & 27 & 1.3 & 7.9 & 995 & 65 & 8.74 & $\begin{array}{l}\text { Prednisone } \\
6 \mathrm{MP}\end{array}$ \\
\hline 1.60 & 49.8 & 1.48 & 7.38 & 590 & 51.2 & 6.42 & - \\
\hline 0.41 & 39.5 & 0.49 & 4.04 & 200 & 17.9 & 2.36 & - \\
\hline
\end{tabular}

lating monocytes and the level of immunoglobulins in our patients, and no plasmacytosis of the bone marrow.

No reports are available concerning the serum levels of transferrin, ceruloplasmin, $\alpha_{2}$-macroglobulin, or other proteins in monocytic leukemia. The present study revealed low serum transferrin in 11 patients, in the absence of evidence of hemolysis. Ceruloplasmin was either normal or mildly elevated. $\alpha_{2}$-Macroglobulin was decreased in nine patients. No correlation was found between the low level of transferrin and the low $\alpha_{s}$-macroglobulin, the former being more frequent in patients with normal renal function and the latter in patients with azotemia.

Finch, Gnabasic, and Rogoway (30) and Jolles, Sternberg, and Mathé (13) were the first to report an increased serum level of lysozyme (muramidase) in monoblastic and myelomonocytic leukemia. Correlations have been shown between the level of lysozyme and the number of circulating monocytes and granulocytes ( 7 , 31-33). The marked variability observed in this correlation has been attributed to differences in the rate of production, tissue binding, or renal handling of the enzyme (7). However, it is also possible that the total body pool of lysozyme-producing cells and the rate of destruction of the enzyme may play a role. In our series, the serum lysozyme was elevated in all patients during the active phase of the disease, being higher in the presence of azotemia. Renal failure $(34,35)$ would offer an explanation for the more significant elevation of serum LZM in group B, if it were not for the fact that several of these patients also had much more pronounced peripheral monocytosis than those without azotemia. Therefore, the possibility remains that enhanced production of lysozyme may account for some of this difference.

Osserman and Lawlor and others have noted hypokalemia and hyperkaluria in a number of patients with mono- and myelomonocytic leukemia $(7,14,15,36)$. Excessive excretion rates of potassium, reduced excretion of titratable acid, and glycosuria were also noted in some patients (15). In our series, seven patients had hypokalemia, three of whom also had a low serum calcium. Two of the latter also had a low magnesium and one had hypophosphatemia. In several of these patients, attempts were made to correct the low level of serum potassium by administration of $40-80 \mathrm{mEq}$ of potas- 
TABLE V

Protein Studies in Patients with

\begin{tabular}{|c|c|c|c|c|c|c|c|c|c|c|c|c|c|c|c|c|}
\hline \multirow[b]{2}{*}{ No. } & \multicolumn{2}{|c|}{ Serum } & \multicolumn{2}{|c|}{ Urine } & \multicolumn{3}{|c|}{ Lysozyme } & \multicolumn{3}{|c|}{ Transferrin } & \multicolumn{3}{|c|}{ Ceruloplasmin } & \multicolumn{3}{|c|}{ IgG } \\
\hline & $\begin{array}{c}\text { Total } \\
\text { protein }\end{array}$ & $\begin{array}{c}\text { Gamma } \\
\text { globu- } \\
\text { lin }\end{array}$ & $\begin{array}{c}\text { Total } \\
\text { protein }\end{array}$ & $\begin{array}{c}\text { Albu- } \\
\text { min }\end{array}$ & Serum & Urine & $\begin{array}{l}\text { Clear- } \\
\text { ance }\end{array}$ & Serum & Urine & $\begin{array}{l}\text { Clear- } \\
\text { ance }\end{array}$ & Serum & Urine & $\begin{array}{l}\text { Clear- } \\
\text { ance }\end{array}$ & Serum & Urine & $\begin{array}{l}\text { Clear- } \\
\text { ance }\end{array}$ \\
\hline & \multicolumn{2}{|c|}{$\mathrm{g} / 100 \mathrm{ml}$} & $g / 24 h$ & $\begin{array}{c}\text { \%o of } \\
\text { total } \\
\text { protein }\end{array}$ & $\mu g / m l$ & $m g / 24 h r$ & $\mathrm{ml} / \mathrm{min}$ & $\begin{array}{c}m g / \\
100 m l\end{array}$ & $\begin{array}{l}m g / \\
24 h r\end{array}$ & $\mathrm{ml} / \mathrm{min}$ & $\begin{array}{c}m g / \\
100 \mathrm{ml}\end{array}$ & $\begin{array}{l}m g / \\
24 h r\end{array}$ & $\operatorname{ml} / \min$ & $\begin{array}{c}m g / \\
100 m l\end{array}$ & $m g / 24 h r$ & $m l / m i n$ \\
\hline 1 & 7.10 & 2.23 & 2.21 & 22 & 114 & 595 & 3.62 & 263 & 24.8 & 0.0066 & 100 & 2.21 & 0.0015 & 2440 & 293 & 0.0056 \\
\hline 2 & 7.75 & 2.26 & 0.83 & 30 & 64 & 187 & 2.03 & 213 & 13.5 & 0.0044 & 72 & 2.60 & 0.0025 & 3200 & 40 & 0.00087 \\
\hline 3 & 7.70 & 2.11 & 1.20 & 14 & 58 & 533 & 6.38 & 289 & 52.5 & 0.013 & 82.5 & 1.43 & 0.0012 & 1660 & 132 & 0.0055 \\
\hline 4 & 8.50 & 3.41 & 3.26 & 21 & 150 & 298 & 1.38 & 147 & 11.97 & 0.0057 & 26.5 & 2.58 & 0.0067 & 3000 & 6.83 & 0.00048 \\
\hline 5 & 6.54 & 1.91 & 2.15 & 33 & 52 & 75.5 & 1.01 & 96 & 22.7 & 0.016 & 33 & 0.59 & 0.0012 & 1910 & 27.1 & 0.00098 \\
\hline 6 & 6.25 & 2.52 & 6.24 & 7 & 28.2 & 18.2 & 0.45 & 89 & 10.73 & 0.008 & 35.5 & 1.76 & 0.0034 & 2810 & 69.6 & 0.0017 \\
\hline 7 & 7.63 & 3.67 & 6.64 & 23 & 90 & 1488 & 11.48 & 176 & 5.52 & 0.0022 & 22.4 & 0.96 & 0.003 & 3010 & 445 & 0.047 \\
\hline 8 & 7.18 & 1.31 & 1.26 & 8 & 58 & 1185 & 14.19 & 173 & 5.25 & 0.0021 & 53 & 5.64 & 0.0074 & 1860 & 70.1 & 0.0026 \\
\hline 9 & 5.60 & 0.90 & 4.13 & 3 & 125 & 1940 & 10.77 & 173 & 25.1 & 0.010 & 67 & 25.70 & 0.027 & 930 & 15.44 & 0.0011 \\
\hline & & & & & $111^{*}$ & 1914 & 11.97 & 133 & 17.4 & 0.009 & 75 & 50.40 & 0.047 & & & \\
\hline Mean & 7.14 & 2.26 & 3.10 & 18 & 85 & 823.4 & 6.33 & 175 & 18.95 & 0.0077 & 56.7 & 9.39 & 0.011 & 2313 & 122 & 0.0073 \\
\hline SD & 0.84 & 0.84 & 2.04 & 9.9 & 36.8 & 709.5 & 5.03 & 62 & 13.16 & 0.0043 & 25.2 & 15.41 & 0.010 & 724 & 141 & 0.014 \\
\hline
\end{tabular}

* Second set of estimations done 1 wk after the first.

sium daily without success. Two patients with hypokalemia showed droplet degeneration in the proximal tubular cells and one also had chronic pyelonephritis. There was no correlation between the electrolyte abnor-

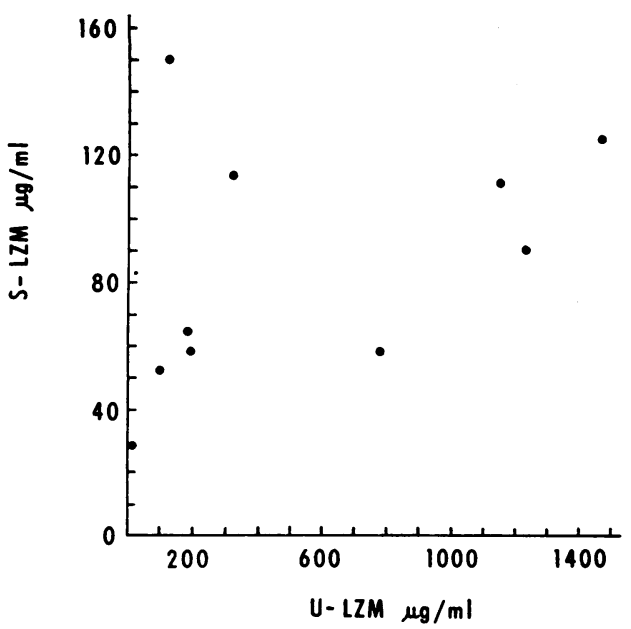

Figure 4 Group B. Relationship between serum lysozyme (S-LZM) and urinary lysozyme (U-LZM), 10 estimations. $r^{2}=0.1665$. Correlation significant at the level $P<0.05$. malities and the level of serum or urinary LZM. Increased serum uric acid levels and hyperuricosuria were noted in one patient of group A and in three of group B. Hyperuricosuria without hyperuricemia was observed in two others. No correlation was found between uricosuria, the level of electrolytes, proteinuria, or lysozyme excretion.

There are no detailed studies on proteinuria in leukemia, although patients with lymphatic leukemia have been found to excrete more protein in the urine than normal persons, particularly in regard to gamma globulins (9). In a series of mono- and myelomonocytic leukemia, proteinuria varying from 1.4 to $6.6 \mathrm{~g} / 24 \mathrm{hr}$ has been recorded, of which lysozyme has constituted up to $40 \%$. Other components have included albumin and some alpha, beta, and gamma globulins (7). While our own control group of healthy subjects aged 21-62 yr showed proteinuria varying from 59 to $187 \mathrm{mg} / 24 \mathrm{hr}$ with a mean of $103 \mathrm{mg}$, in most of our patients the total urinary protein consistently exceeded $300 \mathrm{mg} / 24$ $\mathrm{hr}$, being higher in patients with impaired renal function. Albumin generally constituted less than $25 \%$ of the total protein. Variable amounts of alpha, beta, and gamma globulins were found in all urines, with lyso- 


\begin{tabular}{|c|c|c|c|c|c|c|c|c|c|c|c|c|}
\hline \multicolumn{3}{|c|}{ IgA } & \multicolumn{3}{|c|}{ IgD } & \multicolumn{3}{|c|}{ IgM } & \multicolumn{3}{|c|}{$\alpha \varepsilon-$ Macroglobulin } & \multirow[t]{2}{*}{ Comments } \\
\hline Serum & Urine & $\begin{array}{l}\text { Clear- } \\
\text { ance }\end{array}$ & Serum & Urine & $\begin{array}{l}\text { Clear- } \\
\text { ance }\end{array}$ & Serum & Urine & $\begin{array}{l}\text { Clear- } \\
\text { ance }\end{array}$ & Serum & Urine & $\begin{array}{l}\text { Clear- } \\
\text { ance }\end{array}$ & \\
\hline $\begin{array}{c}m g / \\
100 \mathrm{ml}\end{array}$ & $m g / 24 h r$ & $m l / m i n$ & $\begin{array}{c}m g / \\
100 m l\end{array}$ & $m g / 24 h r$ & $m l / m i n$ & $\begin{array}{c}m g / \\
100 m l\end{array}$ & $m g / 24 h r$ & $m l / m i n$ & $\begin{array}{c}m g / \\
100 \mathrm{ml}\end{array}$ & $m g / 24 h r$ & $m l / m i n$ & . \\
\hline 570 & 24.6 & 0.003 & 16.0 & 17.6 & 0.00076 & 202 & 0 & 0 & 200 & 3.22 & 0.0011 & $\begin{array}{l}\text { Fc and F'c fragments } \\
\text { in the urine }\end{array}$ \\
\hline 1870 & 11.0 & 0.00041 & 6.5 & 0 & - & 275 & 0 & 0 & 263 & 0 & 0 & Sia test $(+)$ \\
\hline 490 & 15.1 & 0.0021 & 10.2 & 2.5 & 0.00017 & 291 & $\mathbf{0}$ & 0 & 260 & 20.71 & 0.0055 & $\begin{array}{l}\text { Fc and } F^{\prime} c \text { fragments } \\
\text { in the urine }\end{array}$ \\
\hline 400 & 14.0 & 0.0024 & $2<$ & 3.2 & - & 510 & 0.9 & 0.00037 & 147 & 10.57 & 0.0050 & $\begin{array}{l}\text { Sia test }(+) ; F c \text { and } \\
\text { F'c fragments in } \\
\text { the urine }\end{array}$ \\
\hline 370 & 39.96 & 0.0075 & $2<$ & $\mathbf{0}$ & 一 & 216 & 17.5 & 0.0056 & 370 & 37.89 & 0.0071 & $\begin{array}{l}\text { Fc and } F^{\prime} c \text { fragments } \\
\text { in the urine }\end{array}$ \\
\hline 338 & 10.4 & 0.0021 & 6.5 & $\mathbf{0}$ & - & 685 & 1.17 & 0.00012 & 23.1 & 6.76 & 0.0020 & $\begin{array}{l}\text { Sia test }(+) ; F c \text { and } \\
\text { F'c fragments in } \\
\text { the urine }\end{array}$ \\
\hline 1250 & 228 & 0.013 & 6.5 & 0 & 一 & 258 & 0 & 0 & 197 & 3.15 & 0.0011 & $\begin{array}{l}\text { Cryoglobulinemia, } \\
\text { Sia test }(+) ; F c \text {, } \\
\text { and F'c fragments } \\
\text { in the urine, Bence } \\
\text { Jones heat test }(+)\end{array}$ \\
\hline 393 & 3.75 & 0.00066 & $2<$ & 37.8 & - & 78 & 31.8 & 0.028 & 250 & 14.40 & 0.040 & $\begin{array}{l}\text { Fc and F'c fragments } \\
\text { in the urine }\end{array}$ \\
\hline 106 & 103 & 0.067 & $2<$ & 146.2 & - & 36 & 257.4 & 0.50 & 130 & 38.84 & 0.0210 & \\
\hline 643 & 30.43 & 0.011 & - & - & - & 283 & - & - & 228 & 15.06 & 0.0092 & \\
\hline 525 & 30.10 & 0.020 & - & - & - & 191 & - & - & 71 & 12.82 & 0.012 & \\
\hline
\end{tabular}

zyme as the predominant constituent in five instances. In one urine, a significant amount of prealbumin and in another a band of postgamma protein, with slightly slower electrophoretic mobility than lysozyme, were also observed. In several patients, the electrophoretic patterns resembled those reported in tubular disorders, such as cadmium poisoning, adult Fanconi syndrome, and others in which excretion of low molecular weight proteins of alpha, beta, and even gamma mobility have exceeded that of albumin. Lysozymuria has frequently been observed in this type of proteinuria (37-43).

Excretion of IgG and IgA, as well as their clearances, were increased as compared to healthy individuals. IgD and $\operatorname{IgM}$ were excreted in the urines of six patients, especially in patients with azotemia. $F c$ and $F^{\prime} c$ fragments were observed in urines from 12 patients while the Bence Jones heat test was positive in two. One patient excreted Bence Jones type kappa globulin for a period of 2 months. While excessive excretion of transferrin was noted in most patients, ceruloplasmin and $\alpha_{2}$-macroglobulin were especially excreted in urines of patients with azotemia.

Increased urinary lysozyme has been reported in various renal disorders particularly in patients with azotemia and proteinuria and in those with proximal tubular dysfunction $(34,35,39,40,44,45)$. More recently, Osser-

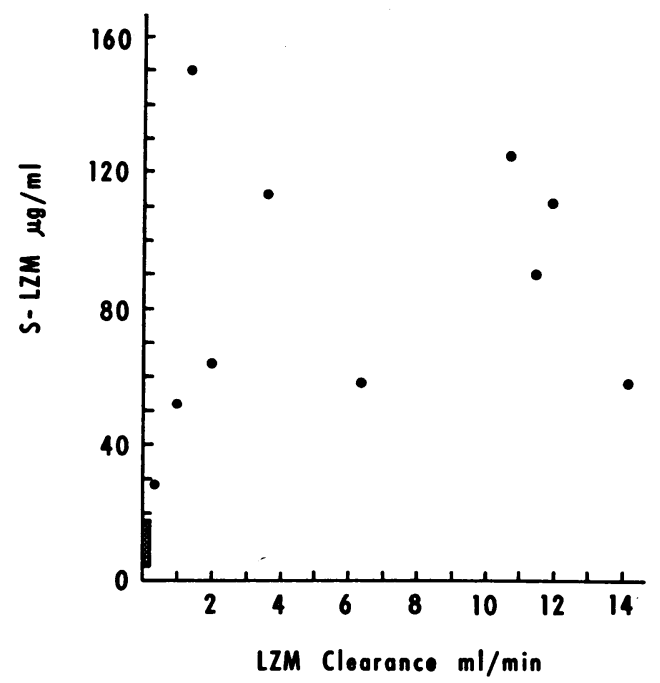

Figure 5 Group B. Relationship between serum lysozyme (S-LZM) and its clearance by the kidneys, 10 estimations. $r^{2}=0.0598$. No statistically significant correlation. Shaded area indicates normal range. 
man and Lawlor and other authors have observed increased lysozymuria in patients with monocytic and monomyelocytic leukemia $(7,31,46)$. In our series, the excretion of lysozyme was increased approximately 90 -fold in group A and 520 -fold in group B. In patients with azotemia, no correlation was found between the serum level of lysozyme and its renal clearance. It has been reported that the clearance of LZM is not so great as might be anticipated from its molecular weight (44, 47 ). Since LZM is probably partly bound to the serum proteins (47), its actual glomerular filtration may be lower than that which might be expected for a substance of similar molecular weight and of comparable serum concentration. It is also possible that the tubular reabsorption of LZM, which normally exceeds $99 \%$ of the glomerular-filtered enzyme (48), is impaired by the toxic effect of LZM itself. In our patients, in the majority of instances, the serum and urinary lysozyme levels were proportionately high. However, on four occasions, the level of urinary lysozyme was normal despite an elevated lysozyme in the serum. In these patients, although lysozyme may have been filtered excessively through the glomeruli, apparently it was efficiently reabsorbed by the tubular cells. In five other instances, a high concentration of urinary lysozyme was noted in the presence of a normal or only slightly elevated serum level of the enzyme and normal renal function. Since lysozyme is continuously elaborated by the leukemic cells and glomerular filtration was normal in these instances, one might postulate impaired reabsorption and(or) active tubular secretion of the enzyme or its leakage from the damaged tubular cells.

From the above data, it is evident that the patients with mono- and myelomonocytic leukemia almost invariably develop prominent proteinuria and that azotemia develops in approximately $50 \%$ of cases. Among 12 additional patients with this disease recently studied and not included in the present series, nine had proteinuria and six had azotemia. In contrast to this, a comparative study of 37 patients with other types of leukemia revealed proteinuria only occasionally and azotemia very rarely. When present, both were usually related to other complicating renal diseases such as pyelonephritis (49). Any explanation for the renal damage observed therefore must take into account at least two major differences between monocytic leukemia and other types of leukemia, namely the prominent hypergammaglobulinemia and the increase in lysozyme production with subsequent lysozymuria.

It has been reported that hypergammaglobulinemia may contribute to the development of renal tubular acidosis (50). Hypergammaglobulinemia and also M-components have been observed in patients with adult Fanconi syndrome $(43,51)$. None of our patients had tu- bular acidosis, aminoaciduria, or glycosuria but all these abnormalities have been reported in a few cases of monocytic leukemia (15). The fact that immunoglobulin levels were frequently much higher in the patients comprising our group B than in those with normal renal function, may be of some importance. Nevertheless, in the absence of renal tubular acidosis, one would question the role of hypergammaglobulinemia as the most important factor in the production of renal tubular injury.

Recent evidence suggests that high concentrations of lysozyme may damage the proximal tubular cells. Normally, lysozyme is reabsorbed in the proximal convoluted tubule and its concentrations in the cortex may be 10-25 times greater than in the medulla (52). Exogenous lysozyme injected into animals concentrates in the proximal tubular cells in the form of droplets which may be detected by light microscopy (53) or by immunofluorescent techniques (54). Renal injury in rats treated with tubular poisons results in greater urinary lysozyme excretion than in those treated with antiglomerular antiserum (34). Osserman has suggested that humans and rats with monocytic leukemia, as well as rats injected with exogenous lysozyme, develop "lysozyme nephropathy" (55). It has been shown that the increased concentration of the enzyme in the kidney may be associated with cytoplasmic droplet degeneration of the proximal tubular cells and distortion of the mitochondria and nuclei $(16,36)$. Similarly, in autopsy material available to us, droplets of homogenous eosinophilic substances have been found in the proximal tubular cells in 4 of 12 cases studied. The higher levels of serum lysozyme in patients comprising our group B may therefore be of considerable significance in contributing to renal tubular injury. It is possible that the low glomerular filtration rate in these patients may lead to the retention of LZM in the serum and subsequently to the higher concentration of the enzyme in the glomerular filtrate. This leads to the inability of the proximal tubular cells to reabsorb all the enzyme filtered. Spillover of LZM into the urine and possible damage to the tubular cells by LZM itself may consequently appear. It seems improbable that occasional intercurrent infections or hyperuricemia, which are usually treated promptly, contribute to the renal damage.

The analyses of the proteins excreted in the urine would appear to suggest the tubular as well as glomerular dysfunction. In many instances, the electrophoretic patterns of the urinary proteins including a low albumin and an excessive excretion of $\alpha-, \beta$, , and $\boldsymbol{\gamma}$-globulins, resembled those seen in various tubular disorders. On the other hand, the presence of high molecular weight proteins in the urine suggests that glomerular damage also occurred. The pathogenesis of azotemia and renal 
failure which were found in $50 \%$ of the patients with mono- and myelomonocytic leukemia has not yet been elucidated. Recent observations on the glomerular damage in myeloma (56) or on azotemia found in patients with adult Fanconi syndrome (43), may imply that, in conditions involving mainly tubular cells, glomerular damage may also occur.

From the comparative study of various leukemias, this particular glomerular-tubular dysfunction appears to be a manifestation unique to mono- and myelomonocytic leukemia.

\section{ACKNOWLEDGMENTS}

Our thanks to Dr. M. A. Ogryzlo, Dr. D. E. Bergsagel, and Dr. A. Bruce-Robertson for their contribution in the preparation of the paper; to Mrs. S. Saito for the technical help; and to Miss M. E. A. Bliss for the photographs.

This work was supported by a grant-in-aid from the Ontario Cancer Treatment and Research Foundation (220).

\section{REFERENCES}

1. Fahey, J. L. 1965. Antibodies and immunoglobulins. II. Normal development and changes in disease. J. Amer. Med. Ass. 194: 255.

2. Sinn, C. M., and F. W. Dick. 1956. Monocytic leukemia. Amer. J. Med. 20: 588.

3. Bergsagel, D. E. 1967. The chronic leukemias: a review of disease manifestations and the aims of therapy. Can. Med. Ass. J. 96: 1615.

4. Ryder, R. J. W. 1966. Chronic monocytic leukemia. Blut. 14: 47.

5. Osserman, E. F. 1967. The Association between plasmacytic and monocytic dyscrasias in man: clinical and biochemical studies. In Gamma Globulins. Structure and Control of Biosynthesis. Nobel Symposium 3, J. Killander, editor. Almqvist \& Wiksells, Publishers, Stockholm.

6. Brown, R. K., J. T. Read, B. K. Wiseman, and W. G. France. 1948. The electrophoretic analysis of serum proteins of the blood dyscrasias. J. Lab. Clin. Med. 33: 1523.

7. Osserman, E. F., and D. P. Lawlor. 1966. Serum and urinary lysozyme (muramidase) in monocytic and monomyelocytic leukemia. J. Exp. Med. 124: 921.

8. Perillie, P. E., S. S. Kaplan, E. Lefkowitz, and S. C. Finch. 1966. Muramidase (lysozyme) activity in leukemia. Blood. 28: 1000.

9. Nettleship, A., J. A. Strother, and H. S. Smith. 1963. Relationship of serum and urinary proteins in neoplastic states: a preliminary survey. Clin. Chem. 9: 608.

10. Rieselbach, R. E., C. J. Bentzel, E. Cotlove, E. Frei III, and E. J. Freireich. 1964. Uric acid excretion and renal function in the acute hyperuricemia of leukemia. Pathogenesis and therapy of uric acid nephropathy. Amer. J. Med. $37: 872$.

11. Vogler, W. R., J. A. Bain, C. M. Huguley, Jr., H. G. Palmer, Jr., and M. D. Lowrey. 1966. Metabolic and therapeutic effects of allopurinol in patients with leukemia and gout. Amer. J. Med. 40: 548.

12. Norris, H. J., and J. Wiener. 1961. The renal lesions in leukemia. Amer. J. Med. Sci. 241: 512.

13. Jolles, P., M. Sternberg, and G. Mathé. 1965. The relationship between serum lysozyme levels and the blood leukocytes. Israel J. Med. Sci. 1: 445.
14. Muggia, F., H. O. Heinemann, and E. F. Osserman. 1967. Hypokalemia in cases of monocytic leukemia with lysozymuria. J. Clin. Invest. 46: 1098.

15. Muggia, F. M., H. O. Heinemann, M. Farhangi, and E. F. Osserman. 1969. Lysozymuria and renal tubular dysfunction in monocytic and myelomonocytic leukemia. Amer. J. Med. 47: 351.

16. Osserman, E. F., and H. A. Azar. 1969. Renal tubular lesions secondary to lysozyme in human and rat monocytic leukemia. Fed. Proc. 28: 619.

17. Pruzanski, W., and S. G. Saito. 1969. The diagnostic value of lysozyme (muramidase) estimation in biological fluids. Amer. J. Med. Sci. 258: 405.

18. Hiller, A., R. L. Greig, and W. W. Beckman. 1948. Determination of protein in urine by biuret method. J. Biol. Chem. 176: 1421.

19. Grabar, P., and C. A. Williams, Jr. 1955. Methode immunoelectrophoretique d'analyse de melanges de substances antigeniques. Biochim. Biophys. Acto. 17: 67.

20. Alderton, G., W. H. Ward, and H. L. Fevold. 1945. Isolation of lysozyme from egg-white. J. Biol. Chem. 157: 43.

21. Jackson, S. H., I. B. Sardharwalla, and G. C. Ebers. 1968. Two systems of amino acid chromatography suitable for mass screening. Clin. Biochem. 2: 163.

22. Roberts, R. C., D. G. Makey, and U. S. Seal. 1966. Human transferrin, molecular weight and sedimentation properties. J. Biol. Chem. 241: 4907.

23. Joachim, G. R., J. S. Cameron, M. Schwartz, and E. L. Becker. 1964. Selectivity of protein excretion in patients with the nephrotic syndrome. J. Clin. Invest. 43: 2332.

24. MacLean, P. R., and J. S. Robson. 1967. A simple method for determining selectivity of proteinuria. Lancet. 1: 539.

25. Fahey, J. L., and D. R. Boggs. 1960. Serum protein changes in malignant diseases. I. The acute leukemias. Blood. 16: 1479.

26. Boggs, D. R., and J. L. Fahey. 1960. Serum-protein changes in malignant disease. II. The chronic leukemias, Hodgkin's disease and malignant lymphoma. J. Nat. Cancer Inst. 25: 1381.

27. Sunderman, F. W., Jr., and M. W. Johnson. 1966. Studies of the serum proteins. VII. Sucrose gradient electrophoresis. Amer. J. Clin. Pathol. 45: 381.

28. Wildhack, R. 1967. Monozytenleukemie mit $\gamma$ G-Paraproteinamie nach Roentgennachbestrahlung und zytostatischer Behandlung eines Myosarkoms. Deut. Med. Wochenschr. 92: 255.

29. Poulik, M. D., L. Berman, and A. S. Prasad. 1969 "Myeloma protein" in a patient with monocytic leukemia. Blood. 33: 746.

30. Finch, S. C., F. J. Gnabasic, and W. Rogoway. 1964 Lysozyme and Leukopoiesis. Proceedings of the Third International Symposium on Fleming's Lysozyme. Scuola Arti Grafiche, O. S. F. Cesano Boscone, Milan.

31. Perillie, P. E., S. C. Kaplan, E. Lefkowitz, W. Rogaway, and S. C. Finch. 1968. Studies of muramidase (lysozyme) in leukemia. J. Amer. Med. Ass. 203: 317

32. Noble, R. E., and H. H. Fudenberg. 1967. Leukocyte lysozyme activity in myelocytic leukemia. Blood. 30: 465.

33. Charlmagne, D., and P. Jolles. 1966. Les lysozymes des leukocytes et du plasma d'origine humaine. Hommes normaux et malades atteints de leucemie myeloide chronique. Nouv. Rev. Fr. Hematol. 6: 355. 
34. Prockop, D. J., and W. D. Davidson. 1964. A study of urinary and serum lysozyme in patients with renal disease. N. Engl. J. Med. 270: 269.

35. Hayslett, J. P., P. E. Perillie, and S. C. Finch. 1968. Urinary muramidase and renal disease, correlation with renal histology and implications for the mechanism of enzymuria. N. Engl. J. Med. 279: 506.

36. Wiernik, P. M., and A. A. Serpick. 1969. Clinical significance of serum and urinary muramidase activity in leukemia and other hematologic malignancies. Amer. $J$. Med. 46: 330 .

37. Schultze, H. E., and J. F. Heremans. 1966. Molecular biology of human proteins with special reference to plasma proteins. Vol. 1. Elsevier, Amsterdam.

38. Walravens, P., E. C. Laterre, and J. F. Heremans. 1968. Studies on tubular proteinuria. Clin. Chim. Acta. 19: 107.

39. Piscator, M. 1966. Proteinuria in chronic cadmium poisoning. III. Electrophoretic and immunoelectrophoretic studies on urinary proteins from cadmium workers, with special reference to the excretion of low molecular weight proteins. Arch. Environ. Health. 12: 335.

40. Piscator, M. 1966. Proteinuria in chronic cadmium poisoning. IV. Gel filtration and ion exchange chromatography of urinary proteins from cadmium workers. Arch. Environ. Health. 12: 345.

41. Harrison, J. F., and B. E. Northam. 1966. Low molecular weight urine protein investigated by gel filtration. Clin. Chim. Acta. 14: 679.

42. Butler, E. A., F. V. Flynn, H. Harris, and E. B. Robson. 1962. A study of urine proteins by two-dimensional electrophoresis with special reference to the proteinuria of renal tubular disorders. Clin. Chim. Acta. 7: 34.

43. Harrison, J. F., and J. D. Blainey. 1967. Adult Fanconi syndrome with monoclonal abnormality of immunoglobulin light chain. J. Clin. Pathol. 20: 42.

44. Harrison, J. F., G. S. Lunt, P. Scott, and J. D. Blainey. 1968. Urinary lysozyme, ribonuclease and lowmolecular-weight protein in renal disease. Lancet. 1: 371.

45. Morris, R. C., I. Veki, A. Sebastian, and E. Morris. 1967. Lysozymuria in acidification defects of the proximal nephron. Clin. Res. 15: 142.
46. Jolles, P., M. Bonnafe, A. Mouton, and L. Schwarzenberg. 1967. Dosage automatique du lysozyme dans l'urine de divers leucemiques: caraterisation et purification d'un lysozyme chez les seuls malades, atteints de leucemie myeloblastique aigue. Rev. Fr. Etud. Clin. Biol. 12 : 996.

47. Marshall, M. E., and H. F., Deutsch. 1950. Clearances of some proteins by the dog kidney. Amer. J. Physiol. 163: 461

48. Bottomley, R. H., and S. J. Gallemore. 1970. Lysozyme clearance in patients with acute mono-myeloblastic leukemia. Clin. Res. 18: 399.

49. Pruzanski, W. 1970. Serum and urinary proteins, muramidase and renal function in leukemia. A unique defect in mono- and myelomonocytic type. Proceedings of the XIII International Congress of Hematology, Munich. August 2-8.

50. Morris, R. C., Jr., and H. H. Fudenberg. 1967. Impaired renal acidification in patients with hypergammaglobulinemia. Medicine. 46: 57.

51. Constanza, D. J., and M. Smoller. 1963. Multiple myeloma with the Fanconi syndrome. Study of a case with electron microscopy of the kidney. Amer. J. Med. 34: 125.

52. Sussman, M., A. W. Asscher, and J. A. S. Jenkins. 1968. The intrarenal distribution of lysozyme (muramidase). Invest. Urol. 6: 148.

53. Maack, T. 1967. Changes in the activity of acid hydrolases during renal reabsorption of lysozyme. J. Cell. Biol. 35: 268.

54. Glynn, A. A. 1966. Rôle et répartition du lysozyme intracellulaire et extracellulaire. Exposes. Annu Biochim. Med. 27: 111.

55. Osserman, E. F. 1970. Lysozymuria in renal and nonrenal diseases. In Proteins in Normal and Pathological Urine. Y. Manuel, J. P. Revillard, and H. Betuel, editors. S. Karger AG., Basel. 260.

56. Fisher, E. R., E. Perez-Stable, and Z. A. Zawadzki. 1964. Ultrastructural renal changes in multiple myeloma with comments relative to the mechanism of proteinuria. Lab. Invest. 13: 1561.

57. Rowe, D. S., and J. L. Fahey. A new class of human immunoglobulins. II. Normal serum IgD. J. Exp. Med. 121: 185 . 